\title{
First report of tomato spotted wilt virus infecting Epipremnum aureum in Korea
}

\author{
Hyo-Jeong Lee ${ }^{1} \cdot$ Seong Woong Kim ${ }^{1} \cdot$ Na-Kyeong Kim ${ }^{1} \cdot$ Kwang-Yeol Yang $^{1} \cdot$ Rae-Dong Jeong ${ }^{1} \mathbb{C}$
}

Received: 8 April 2021 / Accepted: 22 July 2021 / Published online: 29 October 2021

(c) Società Italiana di Patologia Vegetale (S.I.Pa.V.) 2021

Keywords Epipremnum aureum $\cdot$ Korea $\cdot$ tomato spotted wilt virus

Epipremnum aureum (family Araceae), a tropical vine commonly known as pothos, is grown commercially worldwide for ornamental use as a garden and indoor plant (Tian et al. 2018). In February 2021, tospovirus-like symptoms including foliar necrotic spots, mosaic, wilting, and yellowing were observed in approximately $20 \%$ of plants in a commercial greenhouse in Gwangju, South Korea (Parrella et al. 2003). To identify the causal virus, sap extracts of symptomatic leaf samples from five $E$. aureum plants were examined by transmission electron microscopy after negative staining with $1 \%$ uranyl acetate; tospovirus-like spherical particles of 80 to $100 \mathrm{~nm}$ in diameter were observed in all samples. Ten symptomatic leaf samples and two asymptomatic leaf samples were further analyzed with DAS-ELISA kits (Agdia, Elkhart, IN, USA) using antisera to major tospoviruses reported in Korea, including impatiens necrotic spot virus and tomato spotted wilt virus (TSWV). TSWV was detected in all symptomatic plants, but not in asymptomatic plants. To confirm the presence of TSWV, total RNA was extracted from ELISA-positive samples and analyzed by RT-PCR using TSWV-specific primers (Choi et al. 2018). The amplified fragments were cloned into pGEM-T vector (Promega, Madison, WI), and sequenced. The sequences of each fragment were identical, and a representative isolate named TSWV-EA (LC622166), was found to show 95.8\% to $99.5 \%$ nucleotide identity with known TSWV isolates. Healthy E. aureum plants mechanically inoculated with sap from TSWV-infected E. aureum plants showed mild mosaic and systemic necrosis at 14 days post-inoculation. TSWV was subsequently detected in inoculated $E$. aureum based on RT-PCR analysis using the aforementioned primers. To

Rae-Dong Jeong

jraed2@jnu.ac.kr

1 Department of Applied Biology, Chonnam National

University, Gwangju 61185, Korea the best of our knowledge, this is the first report of TSWV infecting E. aureum in Korea; therefore, large-scale monitoring for TSWV infection in E. aureum is required to prevent the spread of this viral disease.

Funding This work was supported by Korea Institute of Planning and Evaluation for Technology in Food, Agriculture, Forestry and Fisheries (IPET) through, Agriculture, Food and Rural Affairs Convergence Technologies Program for Educating Creative Global Leader Program, funded by Ministry of Agriculture, Food and Rural Affairs (MAFRA) (321001-03).

\section{Declarations}

Ethical approval This article does not contain any studies with human participants or animals performed by any of the authors.

Conflict of interest The authors declare that they have no conflict of interest.

\section{References}

Choi GW, Kim B, Ju H, Cho S, Seo E, Kim J, Park J, Hammond J, Lim HS (2018) Dual infections of tomato mosaic virus and tomato yellow leaf curl virus, or tomato mosaic virus and tomato chlorosis virus, detected in tomato fields located in Chungcheonnam-do in 2017. Korean J Agric Sci 45(1):38-42

Parrella G, Gognalons P, Gebre-Selassiè K, Vovlas C, Marchoux G (2003) An update of the host range of tomato spotted wilt virus. J Plant Pathol 85:227-264

Tian N, Han L, Chen C, Wang Z (2018) The complete chloroplast genome sequence of Epipremnum aureum and its comparative analysis among eight Araceae species. PLoS One 13(3):e0192956

Publisher's Note Springer Nature remains neutral with regard to jurisdictional claims in published maps and institutional affiliations. 